\title{
Peran Kelompok Tani Terhadap Kondisi Perekonomian Petani
}

Kasdir Maulana, Program Studi Agribisnis, Universitas Muhammadiyah Parepare, Email: Kasdirmaulana3@gmail.com

\begin{abstract}
Abstrak
Salah satu usaha pemerintah bersama petani dalam rangka membangun kemandiriannya adalah dengan membentuk kelompok-kelompok tani di pedesaan. Tujuan penelitian ini adalah untuk mengetahui peran kelompok tani yang paling dirasakan oleh anggotanya. Metode analisis yang digunakan dalam penelitian ini adalah metode analisis deskriptif dengan pendekatan kualitatif. Hasil penelitian menunjukan bahwa peran kelompok tani yang yang paling dirasakan oleh anggota kelompok tani adalah sebagai kelas/ wahana belajar $48.78 \%$ dan wahana kerjasama $63.41 \%$.
\end{abstract}

Kata Kunci : Peran, Kelompok Tani

Abstract

One of the government's efforts with farmers in order to build their independence is by forming farmer groups in rural areas. The objective of the research is to know the role of the farmer group. Data analysis technique used in this research is a descriptive method with qualitatif approach. The results showed that the most sensible roles of the farmer group are as learningclass $48.78 \%$ and cooperation vehicle $63.41 \%$.

Keywords : The Role; Farmers Group

\section{Latar Belakang}

Pertanian memiliki arti penting dalam pembangunan perekonomian bangsa Indonesia. Pemerintah telah menetapkan pertanian sebagai prioritas utama pembangunan dimasa mendatang. Pembangunan pertanian yang dikelola dengan baik dan bijak akan dapat meningkatkan pertumbuhan dan sekaligus pemerataan ekonomi secara berkelanjutan, mengatasi kemiskinan dan pengangguran, yang pada akhirnya mensejahterakan masyarakat Indonesia secara keseluruhan (Budiarta, dkk., 2017).

Permasalahan yang sering dihadapi petani dari segi produksi biasanya berupa kegagalan panen dan dari tingkat harga biasanya berupa harga penjualan hasil tani yang sangat rendah. Oleh karena itu petani tidak bisa memenuhi kekurangan biaya produksi pertanian dan biaya kebutuhan hidup karena adanya kerugian. Masalahmasalah mendasar lain yang ditemukan adalah sulitnya akses terhadap sumber kapital, informasi, dan teknologi. Organisasi petani masih diharapkan sebagai komponen pokok dalam pembangunan pertanian, namun kondisinya saat ini belum memuaskan (Suhaeti dkk, 2014).

Organisasi petani yang dimaksudkan dalam penelitian ini adalah kelompok tani. Hal ini salah satu usaha 
pemerintah bersama petani dalam rangka membangun upaya kemandiriannya dengan membentuk kelompok-kelompok tani di pedesaan. .Kelompok tani menghendaki terwujudnya pertanian yang baik, usahatani yang optimal dan keluarga tani yang sejahtera dalam perkembangan kehidupannya. Para anggota dibina agar berpandangan sama, berminat yang sama dan atas dasar kekeluargaan (Nainggolan dkk, 2014).

Kelompok tani adalah kumpulan petani yang terikat secara non formal dan dibentuk atas dasar kesamaan, kepentingan, kesamaan kondisi lingkungan (sosial, ekonomi, sumberdaya), keakraban dan keserasian, serta mempunyai pimpinan untuk mencapai tujuan bersama (Nainggolan dkk, 2014). Berdasarkan Peraturan Menteri Pertanian Nomor.67/Permentan/SM.050/12/2016, dalam Rinaldi dkk. (2015), kelompok tani memiliki ciri-ciri sebagai berikut: (a)Saling mengenal, akrab, dan saling percaya diantara sesama anggota; (b)Mempunyai pandangan dan kepentingan yang sama dalam berusaha tani; (c)Memiliki kesamaan dalam tradisi dan atau pemukiman, hamparan usaha, jenis usaha, status ekonomi maupun sosial, bahasa, pendidikan dan ekologi; (d)Ada pembagian tugas dan tanggung jawab sesama anggota berdasarkan kesepakatan bersama.

Peran kelompok tani yang mengacu pada Permentan tersebut adalah : (a) Kelas belajar, kelompok tani merupakan wadah belajar mengajar bagi anggotanya guna meningkatkan pengetahuan, keterampilan dalam berusahatani; (b) Wahana kerjasama, kelompok tani merupakan tempat untuk memperkuat kerjasama diantara sesama petani dalam kelompok tani dan antar kelompok tani serta dengan pihak lain; (c) Unit produksi, sebagai unit produksi, kelompok tani diarahkan untuk memiliki kemampuan mengambil keputusan dalam menentukan pengembangan produksi yang menguntungkan (Tarigan dkk., 2017).

Kondisi perekonomian petani di Desa Banti Kecamatan Baraka Kabupaten Enrekang pada saat ini mengalami krisis dalam bidang pendapatan, karena pada saat ini masyarakat khususnya petani bawang merah tidak mendapatkan hasil yang memuaskan dari hasil pertanian mereka. Hal tersebut disinyalir akibat busuknya tanaman dan menurunya harga bawang merah. Meski demikian petani tidak pernah merasa lelah dan patah semangat dalam melakukan kegiatan pertaniannya, dimana para petani mengambil kegiatan lain agar bisa mencukupi kebutuhan keluarganya dengan cara menanam tanaman hortikultura lainnya, atau bahkan dialihkan ke tanaman tomat dan cabai. Hal ini dilakukan petani dengan harapan dapat memperbaiki keadaan ekonomi petani yang semakin merosot.

\section{Tujuan penelitian}

Mengetahui peran kelompok tani yang paling dirasakan oleh anggotanya.

\section{Bahan dan Metode}

Penelitian ini merupakan penelitian deskriptif dengan pendekatan kualitatif. Lokasi penelitian ditentukan dengan menggunakan metode purposive area, dengan populasi sebagai objek penelitian sebanyak 207 orang dari 9 kelompok tani yang ada dan jumlah sampelnya adalah 41 orang di Desa Banti, Kecamatan Baraka, 
Kabupaten Enrekang. Penarikan sampel ini dilakukan dengan pertimbangan apabila subjek kurang 100 lebih baik populasi diambil semua sebagai sampel, tetapi kalau lebih dari 100 maka dapat diambil $10-15 \%$ atau $20-25 \%$ atau lebih (Arikunto, 2002). Metode pengumpulan data dalam penelitian ini yaitu dengan menggunakan wawancara, observasi, dan dokumentasi. Analisis data yang digunakan yaitu reduksi data, penyajian data dan penarikan kesimpulan. Analisis Data yang digunakan untuk melihat apa saja peran kelompok tani yang paling dirasakan oleh anggota kelompok, menggunakan analisis deskriptif dengan tabel distribusi frekuensi dan persentase dari setiap variabel.

\section{Hasil dan Pembahasan}

\section{Kelompok Tani Sebagai Kelas Belajar}

Kelompok tani merupakan wadah belajar mengajar bagi anggotanya guna meningkatkan pengetahuan, keterampilan dan sikap serta tumbuh dan berkembangnya kemandirian dalam berusahatani. Adapun kategori peran kelompok tani sebagai kelas belajar di Desa Banti, Kecamatan Baraka, Kabupaten Enrekang dapat dilihat pada tabel 1.

Tabel 1. Menurut Kategori Kelas/ Wahana Belajar

\begin{tabular}{llcc}
\hline & & \multicolumn{2}{c}{ Frekuensi } \\
\cline { 3 - 4 } No. & Kategori & Jumlah & Persentase \\
& & $(\mathrm{N})$ & $(\%)$ \\
\hline $\mathbf{1}$ & Rendah & 9 & 21.95 \\
$\mathbf{2}$ & Sedang & 12 & 29.27 \\
$\mathbf{3}$ & Tinggi & 20 & 48.78 \\
\hline & Jumlah & 41 & 100 \\
\hline
\end{tabular}

Sumber : Data primer diolah

Sebaran data tertinggi yaitu $48.78 \%$ dari sampel menunjukkan kelompok tani sebagai kelas belajar sangat mereka sadari namun sebagian besar petani sebagai anggota kelompok tani relatif jarang mengikuti pertemuan rutin dalam membahas usahatani mereka, sehingga ketika mengalami kegagalan bertani sulit mendapatkan solusi. Hal tersebut disadari oleh mereka sebagai salah satu faktor menurunnya produksi yang selanjutnya berimplikasi pada tingkat ekonomi petani setempat. Pengetahuan awal yang dapat dideteksi seharusnya mereka bagi untuk memperoleh solusi atas masalah dalam usahatani mereka melalui pertemuan rutin kelompok taninya.

\section{Kelompok Tani Sebagai Wahana Kerjasama}

Kelompok tani merupakan tempat untuk memperkuat kerjasama diantara sesama petani dalam kelompok tani, antar kelompok tani, dan atau pihak lain. Kategori peran kelompok tani sebagai wahana kerjasama dapat dilihat pada tabel 2.

Tabel 2. Menurut Kategori Wahana Kerjasama

\begin{tabular}{llcc}
\hline & & \multicolumn{2}{c}{ Frekuensi } \\
\cline { 3 - 4 } No. & Kategori & $\begin{array}{c}\text { Jumlah } \\
(\mathrm{N})\end{array}$ & $\begin{array}{c}\text { Persentase } \\
(\%)\end{array}$ \\
\hline $\mathbf{1}$ & Rendah & 5 & 12.20 \\
$\mathbf{2}$ & Sedang & 10 & 24.39 \\
$\mathbf{3}$ & Tinggi & 26 & 63.41 \\
\hline & Jumlah & 41 & 100 \\
\hline
\end{tabular}

Sumber : Data primer diolah

Sebaran data tertinggi yaitu $63.41 \%$ dari kategori kerjasama diantara sesama petani dalam kelompok tani secara sadar digambarkan melalui Tabel 2, bahwa mereka tidak mungkin bisa bekerja sendiri, menutup akses komunikasi diantara petani terlebih dalam kelompoknya sendiri. Para petani sebagai anggota kelompok tani saling membutuhkan informasi untuk kelancaran usahataninya, mulai persiapan 
tanam hingga pemasaran, termasuk mengembangkan usaha tanaman lain yang bisa menjadi sumber alternatif saat produksi menurun dan harga pasaran anjlok.

Kelompok tani secara tidak langsung dapat dipergunakan sebagai salah satu usaha untuk meningkatkan produktivitas usahatani melalui pengelolaan usahatani secara bersamaan. Dengan membentuk kelompok akan lebih mudah mencapai tujuan yang dinginkan dibandingkan dengan bekerja sendiri atau perorangan. Hal ini dikarenakan dengan kegiatan berkelompok, petani bisa saling bertukar pikiran, pengalaman, pengetahuan, dan kemampuan berinovasi untuk menjadikan sistem pertanian menjadi lebih maju.

\section{Kelompok Tani Sebagai Unit Produksi Usahatani}

Sebagai unit produksi, kelompok tani diarahkan untuk memiliki kemampuan mengambil keputusan dalam menentukan pengembangan produksi yang menguntungkan. Kategori peran kelompok tani sebagai unit produksi usahatani dapat dilihat pada tabel 3.

Tabel 3. Menurut Kategori Unit Produksi

\begin{tabular}{llcc}
\hline & & \multicolumn{2}{c}{ Frekuensi } \\
\cline { 3 - 4 } No. & Kategori & $\begin{array}{c}\text { Jumlah } \\
(\mathrm{N})\end{array}$ & $\begin{array}{c}\text { Persentase } \\
(\%)\end{array}$ \\
\hline $\mathbf{1}$ & Rendah & 18 & 43.90 \\
$\mathbf{2}$ & Sedang & 13 & 31.71 \\
$\mathbf{3}$ & Tinggi & 10 & 24.39 \\
\hline & Jumlah & 41 & 100
\end{tabular}

Sumber : Data primer diolah

Sebaran data tertinggi yaitu 43.90

$\%$ dari kategori Distribusi sampel berdasarkan data lapangan menggambarkan jika kapasitas mereka relatif rendah dalam pengambilan keputusan terhadap pilihan komoditas yang akan ditanam sebagai tanaman utama dan alternatif dalam meningkatkan perekonomian petani sekitar. Hal tersebut juga diakui beberapa petani sampel yang menjadi alasan mereka jarang menghadiri pertemuan rutin kelompok tani di lokasi penelitian ini.

Sebagai sarana dan unit produksi bagi petani, kelompok tani dibentuk untuk meningkatkan pengetahuan dan keterampilan mereka dalam bidang pertanian, berbagi pengalaman untuk memecahkan masalah-masalah yang ada di lapangan baik melalui agen penyuluh pendamping pertanian maupun antar kelompok tani. Selain itu, kelompok tani juga mengembangkan penguatan baik dari segi permodalan, penyediaan pupuk, penyediaan pakan, dan pengembangan kemitraan.

\section{Simpulan}

Berdasarkan distribusi sampel terhadap tiga kategori peran kelompok tani yang paling dirasakan oleh petani sebagai anggota kelompok tani di Desa Banti, Kecamatan Baraka, Kabupaten Enrekang adalah peran kelompok sebagai kelas belajar dan wahana kerjasama. Ini ditunjukkan bahwa sebanyak $48.78 \%$ yang menilai jika kelompok tani merupakan wadah belajar mengajar bagi anggotanya guna meningkatkan pengetahuan, keterampilan dan sikap serta tumbuh dan berkembangnya kemandirian dalam berusahatani dan $63.41 \%$ yang menilai jika kelompok tani merupakan tempat untuk memperkuat kerjasama diantara sesama petani dalam kelompok tani, antar kelompok tani, dan atau pihak lain. Hanya $24.39 \%$ sampel yang menilai jika kelompok tani memiliki kemampuan mengambil keputusan dalam menentukan 
pengembangan produksi yang menguntungkan.

\section{Daftar Pustaka}

Arikunto, Suharsimi, 2002. Prosedur Penelitian Suatu Pendapatan Praktek Edisi Revisi 5. Rineka Cipta. Jakarta.

Budiarta, M., Alimuddin Laapo, Abdul Hamid. 2017. Peran Kelompok Tani Terhadap Pendapatan Usahatani Padi Di Desa Purwosari Kecamatan Torue Kabupaten Parigi Mautong. EJournal Geo- Tadulako UNTAD

Nainggolan, Kaman, Mukti,I, Erdiman. 2014. Teknologi Melipatgandakan Produksi Padi Nasional. Gramedia Pustaka Utama, Jakarta.

Rinaldi Prasetia, dan Begem Viantimala. 2015. Peranan Kelompok Tani
Dalam Peningkatan Pendapatan Petani Kopi Di Kelurahan Tugusari Kecamatan Sumberjaya Kabupaten Lampung Barat. Jurnal Agrobisnis, Vol. 3 No. 3 (Juni 2015).

Suhaeti, Rita N dkk. 2014. Arah Kebijakan Pasca Revisi Undang-Undang Perlindungan dan Pemberdayaan Petani. Pusat Sosial Ekonomi dan Kebijakan Pertanian, Bogor.

Tarigan, NA., Sinar Indra K., M.Jufri. 2017. Peran Kelompok Tani Dalam Meningkatkan Produktivitas Usahatani Padi Sawah (Oryza sativa L.) (Kasus: Desa Medan Krio, Kecamatan Sunggal, Kabupaten Deli Serdang). https://jurnal.usu.ac.id/index.php/c eress/article/view/21345 